\title{
Clinical and Epidemiological profile of Anemia in central India
}

\author{
Ratre BK ${ }^{1}$, Patel NP ${ }^{2}$, Patel $\mathbf{U}^{3}$, Jain $\mathbf{R}^{4}$, Sharma VK \\ ${ }^{1}$ Dr Bhupendra Kumar Ratre, Associate Professor* in Medicine, ${ }^{2}$ Dr Narmada Prasad Patel, Assistant Professor* in Medicine, \\ ${ }^{3}$ Dr Umesh Patel, Associate Professor* in Pediatrics, ${ }^{4}$ Dr Roopesh Jain, Associate Professor* in Anesthesia, ${ }^{5}$ Dr V K Sharma, \\ Professor in Medicine, GMC, Bhopal, India. *All are affiliated with L N Medical college, Bhopal, India.
}

Address for correspondence: Dr Bhupendra Kumar Ratre, Email: bkratre@gmail.com

\begin{abstract}
Background: The present, hospital based prevalence study has been conducted to assess the clinical and epidemiological profile of anemia in central India. Methods: In this study 200 patients of anemia from medical out patients department and indoor wards, age between 15-70 years, randomly selected without any bias for sex, occupation, socio-economic status and duration of disease. Results: This study shows that maximum number of patients (40\%) were from age group 21-30 years. Between 15-30 years age group, prevalence of anemia was more in females than males. 57\% study population have moderate anemia and $41 \%$ patients have severe anemia. Weakness \& easy fatigability were most common (100\%) presenting symptoms and pallor was most common (98\% patients) clinical sign. Microcytic and hypochromic type peripheral smear was most common laboratory findings (59\% cases). Nutritional anemia was the most common type of anemia (84\%). Conclusions: Nutritional deficiency anemia is the most common cause of anemia among population, and iron deficiency is the most common nutritional deficiency in population.
\end{abstract}

Key words: Anemia, Iron deficiency, Microcytic anemia, Nutritional anemia

\section{Introduction}

Anemia is a major global health problem, especially in developing countries like India, despite the fact that this problem is largely preventable \& easily treatable. It is the commonest disease affecting humankind and is responsible for morbidity and mortality among general population.

About $30 \%$ or nearly one third of world's population is suffering from anemia due to various causes. ${ }^{1-4}$ In India prevalence is very high as compared to world prevalence. ${ }^{5,8}$ In India prevalence is approximately $51 \%$. Impact of anemia is more on pregnant women and children. ${ }^{6-14}$ The term "Anemia" refers to reduction below normal in the concentration of hemoglobin, Hematocrit or Red blood cells in the blood. Any of the three measures of concentrate (Hemoglobin, Hematocrit, or Number of Red cells) may be used to establish the presence of anemia, but the blood hemoglobin level is preferred, in part because of its accuracy and reproducibility.

Anemia can be of various types, but most common in developing countries is nutritional anemia. Nutritional

Manuscript received: $14^{\text {th }}$ Oct 2013

Reviewed: $29^{\text {th }}$ Oct 2013

Author Corrected: $15^{\text {th }}$ Nov 2013

Accepted for Publication: 19 $9^{\text {th }}$ Dec 2013 anemia can be due to Iron deficiency (most common cause), Folic acid deficiency, Vitamin B12 deficiency or may be combination of these factors, which can present with dimorphic picture. These conditions are seen in all types of medical practice ranging from neonatology to geriatrics and public health and are an ongoing concern to all physicians. Other types include hemolytic anemia, which can be either congenital or acquired. Congenital causes include membrane defect, hemoglobin defects and enzyme defect while acquired causes can be immune or non- immune. Aplastic anemia, anemia due to blood loss and anemia of chronic disease are the some other types of anemia $^{15-17}$.

In India Anemia Control programme was launched in 1970 and after 15 years evaluation of programme was carried out by ICMR. Evaluation showed that the programme failed to make any noticeable impact in reducing incidence of anemia.

Later on anemia prophylaxis programme was reviewed and renamed as "National Nutritional anemia control programme" in 1990. ${ }^{18}$ Later on in 1997, this programme was made an integral part of nationwide "Reproductive \& Child Health" (RCH) programme. Important problem 
posed by anemia in our country is its polymorphism. In the majority of cases the anemia is caused by multiple factors. Deficiency of Iron is manifested by microcytic hypochromic anemia with hyper cellular bone marrow ${ }^{19}$ 21 , deficiency of folic acid and / or vitamin B12 is manifested by macrocytic anemia and a hyper cellular bone marrow with megaloblast, giant cells, metamyclocyte and abnormal megakaryocyte..$^{22,23,24}$ Nutritional macrocytic anemia (NMA) in general population and in pregnancy, commonly seen in India, probably represents combined deficiency of iron, folic acid and vitamin $\mathrm{B} 12^{25-27}$.

Dimorphic anemia, which is due to a combined deficiency of Iron and folic acid and / or vitamin B12, has been described by Indian authors ${ }^{28-30}$.

The present study was planned with the concept to study the type of anemia, various causative risk factors associated with anemia and clinico-pathological manifestations of anemia among population attending medical OPD or admitted in medical ward of Gandhi Medical College \& Associated Hamidia Hospital, Bhopal (MP).

\section{Material and methods}

The present study was a hospital based prevalence study comprising of 200 patients of anemia. Patients were selected from medical out patients department and indoor wards of department of medicine, Hamidia Hospital, Bhopal. These patients were selected at random and belonged to adult age group without any bias for sex, occupation, socio-economic status and duration of disease

\section{Inclusion Criteria}

1. Patients of age 15 years and more.

2. Patients with symptoms, signs and preliminary investigation like hemoglobin level, peripheral blood smear suggestive of anemia.

\section{Exclusion Criteria}

1. All the patients age below 15 years.

2. Patients suffering from chronic infection or other inflammatory states such as tuberculosis, rheumatoid arthritis etc.

3. Anemia due to acute blood loss.

A detailed history was recorded with particular emphasis on symptoms suggestive of anemia such as weakness and easy fatigability, deceased work performance, breathlessness on exertion, pica and peripheral swelling.

A thorough clinical examination of every patient was done especially for pallor, nail changes, glossitis, fundus of eye, cardio vascular involvement in form of tachycardia, haemic murmur, congestive cardiac failure, raised JVP and edema.

Criteria used for diagnosing anemia:-

WHO Criteria for Anemia and Grade of severity ${ }^{(31)}$

\begin{tabular}{|c|c|c|c|c|c|}
\hline & \multirow[t]{2}{*}{ Population } & \multirow{2}{*}{$\begin{array}{l}\text { Non- } \\
\text { Anemia } \\
(\mathrm{Gm} / \mathrm{dL})\end{array}$} & \multicolumn{3}{|c|}{ Anemia $(\mathrm{Gm} / \mathrm{dL})$} \\
\hline & & & Mild & Moderate & Severe \\
\hline 1. & $\begin{array}{l}\text { Children 6- } \\
59 \text { months } \\
\text { of age }\end{array}$ & 11 & $\begin{array}{l}10.0- \\
10.9\end{array}$ & $7.0-9.9$ & $<7.0$ \\
\hline 2. & $\begin{array}{l}\text { Children 5- } \\
11 \text { years of } \\
\text { age }\end{array}$ & 11.5 & $\begin{array}{l}11.0- \\
11.4\end{array}$ & $8.0-10.9$ & $<8.0$ \\
\hline 3. & $\begin{array}{l}\text { Children } \\
12-14 \text { years } \\
\text { of age }\end{array}$ & 12 & $\begin{array}{l}11.0- \\
11.9\end{array}$ & $8.0-10.9$ & $<8.0$ \\
\hline 4. & $\begin{array}{l}\text { Non- } \\
\text { pregnant } \\
\text { women } \\
\text { (15 years of } \\
\text { age and } \\
\text { above) }\end{array}$ & 12 & $\begin{array}{l}11.0- \\
11.9\end{array}$ & $8.0-10.9$ & $<8.0$ \\
\hline 5. & $\begin{array}{l}\text { Pregnant } \\
\text { women }\end{array}$ & 11 & $\begin{array}{l}10.0- \\
10.9\end{array}$ & $7.0-9.9$ & $<7.0$ \\
\hline 6. & $\begin{array}{l}\text { Men } \\
\text { (15 years of } \\
\text { age and } \\
\text { above) }\end{array}$ & 13 & $\begin{array}{l}11.0- \\
12.9\end{array}$ & $8.0-10.9$ & $<8.0$ \\
\hline
\end{tabular}

All the patients under went following investigations:

Initially basic investigation like haemoglobin, Total RBC count and Leukocyte count, platelets count, PCV (Hematocrit), Reticulocyte count, MCV, MCH, MCHC, Peripheral smear examination red cell morphology were assessed.

On the basis of preliminary investigation further investigations were planned according to probable causes of anemia like serum iron, TIBC (Total iron binding capacity), bone marrow examination, stool for ova and cyst specially to see hookworm, stool for occult blood, haemoglobin electrophoresis, sickeling test, serum vitamin B12 level, serum folic acid level, Schilling test for absorption of vitamin B12, G-6-PD Deficiency test. 


\section{Results}

Table No1: Age \& Sex distribution

\begin{tabular}{|c|c|c|c|c|c|c|}
\hline \multirow[t]{2}{*}{ Age in Year } & \multicolumn{4}{|c|}{ No of Patients } & \multirow[t]{2}{*}{ Total No. of Patients } & \multirow[t]{2}{*}{ Percentage } \\
\hline & Male & $\%$ & Female & $\%$ & & \\
\hline $15-20$ & 20 & $10 \%$ & 30 & $15 \%$ & 50 & $25 \%$ \\
\hline 21-30 & 34 & $17 \%$ & 46 & $23 \%$ & 80 & $40 \%$ \\
\hline $31-40$ & 14 & $7 \%$ & 10 & $5 \%$ & 24 & $12 \%$ \\
\hline 41-50 & 22 & $11 \%$ & 4 & $2 \%$ & 26 & $13 \%$ \\
\hline $51-60$ & 10 & $5 \%$ & 2 & $1 \%$ & 8 & $4 \%$ \\
\hline $61-70$ & 6 & $3 \%$ & 2 & $1 \%$ & 8 & $4 \%$ \\
\hline$\geq 70$ \& above & 0 & 0 & 0 & 0 & 0 & 0 \\
\hline Total & 106 & $53 \%$ & 94 & $47 \%$ & 200 & 100 \\
\hline
\end{tabular}

Maximum patients (40\%) were from age group 21-30 years and 25\% patients were from 15-20 years age group. This means $65 \%$ of study population was between 15 to 30 years of age group. Male patients were predominating in the study group except in age group between 15-30 years where female predominance was present.

Table No 2: Severity of Anemia (according to $\mathrm{Hb} \%$ )

\begin{tabular}{|c|c|c|c|c|c|c|}
\hline \multirow{2}{*}{$\begin{array}{l}\text { Grade of } \\
\text { Anemia }\end{array}$} & \multicolumn{2}{|c|}{ Male } & \multicolumn{2}{|c|}{ Female } & \multicolumn{2}{|c|}{ Total } \\
\hline & No & $\%$ & No & $\%$ & No & $\%$ \\
\hline Mild & 03 & 01.5 & 01 & 00.5 & 04 & 02.0 \\
\hline Moderate & 62 & 31.0 & 52 & 26.0 & 114 & 57.0 \\
\hline Severe & 41 & 20.5 & 41 & 20.5 & 82 & 41.0 \\
\hline Total & 106 & 53.0 & 94 & 47.0 & 200 & 100 \\
\hline
\end{tabular}

Above table shows that maximum number of anemic patients (57\%) belongs to moderate category, $41 \%$ patients have severe anemia and only $2 \%$ cases belong to mild category.

Table No 3: Distribution according to presenting symptoms

\begin{tabular}{|c|c|c|}
\hline Symptoms & No of patients & Percentage \\
\hline Weakness \& fatigability & 200 & 100 \\
\hline Decreased work performance & 160 & 60 \\
\hline Breathlessness on exertion & 120 & 40 \\
\hline Swelling over body & 80 & 40 \\
\hline Pain in abdomen & 80 & 60 \\
\hline
\end{tabular}

From this table it is clear that most frequent symptoms were weakness and easy fatigability (100\%), decreased work performance (80\%), breathlessness on exertion (60\%), other important presenting symptoms were swelling over body (40\%), pain in abdomen (40\%), bodyache (28\%), giddiness (20\%), palpitation $(20 \%)$, headache (12\%), anorexia (10\%), worms in stool (10\%), PICA (8\%) and chest pain $(5 \%)$.

Table No 4: Distribution according to Signs

\begin{tabular}{|c|c|c|}
\hline Sign & No of patients & Percentage \\
\hline Pallor & 196 & 98 \\
\hline Nail changes & 120 & 40 \\
\hline Tongue changes & 80 & 40 \\
\hline Edema & 80 & 40 \\
\hline Hepatomegaly & 80 & 40 \\
\hline Tachycardia & 80 & 40 \\
\hline
\end{tabular}


This table depicts important physical findings. Most common finding was pallor of conjunctiva (98\%), 60\% have some form of nail changes, out of which $30 \%$ have typical koilonychias, edema, Hepatomegaly and tachycardia present in $40 \%$ cases.

Other signs like raised JVP (34\%), haemic murmur (28\%), congestive cardiac failure (12\%), Ascitis (12\%), angular Chelitis $(10 \%)$, Anasarca $(10 \%)$ and spleenomegaly $(6 \%)$ were relatively less but important. During fundus examination 80 patient $(40 \%)$ were having pale disc and 20 patient $(10 \%)$ have retinal hemorrhage, 4 patients $(2 \%)$ also have some form of exudates.

Table No 5: Distribution Anemia according to Red Cell morphology in peripheral smear

\begin{tabular}{|c|c|c|c|}
\hline Morphology & No of patients & Percentage & Remark ( No of patients) \\
\hline Microcytic Hypochromic & 118 & 59 & $\begin{array}{c}\text { Iron deficiency-110, } \\
\text { Thalassemia minor-08 }\end{array}$ \\
\hline Dimorphic & 52 & 26 & $\begin{array}{c}\text { Macrocytic hypochromic-36, } \\
\text { Normocytic hypochromic-16 }\end{array}$ \\
\hline Megaloblastic & 18 & 09 & $\begin{array}{c}\text { Vitamin B12 deficiency-12 } \\
\text { Folic acid deficiency-04 } \\
\text { Both -02 }\end{array}$ \\
\hline Normocytic Normochromic & 12 & 06 & $\begin{array}{c}\text { Sickle cell anemia-04 } \\
\text { Aplastic anemia-04 } \\
\text { Others-04 }\end{array}$ \\
\hline Total & 200 & 100 & \\
\hline
\end{tabular}

This table shows 118 (59\%) patients were having microcytic hypochromic picture in peripheral smear, out of them 110 patients have iron deficiency and 08 having Thalassemia minor. 52 patients $(26 \%)$ were having dimorphic picture. In dimorphic anemia 36 patients have macrocytic hypochromic and 16 having normocytic hypochromic picture.

Table No 6: Classification of Anemia.

\begin{tabular}{|c|c|c|}
\hline Type & No. of Patients & Percentage \\
\hline Nutritional Anemia & 168 & 84 \\
\hline Hemolytic anemia & 12 & 6 \\
\hline Due to chronic blood loss & 12 & 2 \\
\hline Aplastic anemia & 4 & 2 \\
\hline Other & 4 & $100 \%$ \\
\hline Total & 200 & 6 \\
\hline
\end{tabular}

This table depicts etiological classification of anemia. 84\% patients were having Nutritional anemia, followed by $6 \%$ having hemolytic anemia, $6 \%$ having anemia due to chronic blood loss. Aplastic anemia was causing 2\% of anemia in study group.

Table No 7: Serum Iron Analysis

\begin{tabular}{|c|c|c|}
\hline Serum Iron $(\boldsymbol{\mu g} / \mathbf{d} \mathbf{l})$ & No of patients & Percentage \\
\hline$<30$ & 48 & $24 \%$ \\
\hline $30-60$ & 120 & $60 \%$ \\
\hline$>60$ & 32 & $16 \%$ \\
\hline Total & 200 & $100 \%$ \\
\hline
\end{tabular}

Table No-07 shows that $24 \%$ patients having serum level $<30 \mu \mathrm{g} / \mathrm{dl}$ while $60 \%$ patients having serum Iron level between 30 $60 \mu \mathrm{g} / \mathrm{dl}$. 


\section{Discussion}

Anemia due to iron deficiency is perhaps the most widespread clinical nutritional deficiency disease in the

world today. Nearly 50 per cent of women of reproductive age and 26 per cent of men in the age group of 15-59 years are anemic (ACC / SCN, 1987 and Beard, 2005). The effects of severe anemia are well established, as compromising work performance and health, others are suggested, such as links with immune competence and resistance to infection ( $A C C / S C N, 1987)$.

The present study was designed to categorize the patients of anemia, study the various causative risk factors responsible for anemia and to study the clinicopathological manifestation of anemia. The cases studied were either those attending medical OPD or those admitted in medical wards of Dept. of medicine, Hamidia Hospital Bhopal.

200 patients of anemia (excluding anemia of chronic diseases) between 15-80 years of age, were studied according to WHO norms. $65 \%$ patients in study were belonging to 15-30 years of age. Male patients constituted $53 \%$ and females constituted $47 \%$ of study group. Though there is no significant difference in percentage of male and female, but slightly male predominance may be because large number of male patient attending medical OPD.

Maximum numbers of female patients $(38 \%$ of total patients) were belonging to age group between 15-30 years. This suggests that most of the female have anemia in early age, especially reproductive age group. 57\% patients were suffering from moderate degree of anemia. Most of the anemic patients $(85 \%)$ were from low and middle socio-economic classes, highlighted the impact of low socioeconomic status on their iron status among these persons. Study done by Verma et al $(1998)^{32,33}$ have found similar results.

Nutritional inadequacy due to unbalance and inadequate diet may be the major cause of anemia in low and middle socioeconomic classes. $60 \%$ patients were from rural areas; this may be because even today $75 \%$ Indian population are living in rural areas and in most of the patients coming to the hospital were resident of rural areas. In our study $58 \%$ patients were from nuclear family, this may be because of changes in lifestyle which lead to shortage of time to select and prepare nutritious food and use of junk \& ready to eat food frequently, which lead to nutritional and iron deficiency. 64\% patients in study group were from Hindu community and
$65 \%$ patients were taking vegetarian diet. Kakkar $\mathrm{R}$ $(2010)^{34}$ has also found nearly similar result $(57 \% \mathrm{Hindu}$ adolescents were anemic) due to the consumption of vegetarian diet with low bioavailability of iron.

Weakness, fatigability, decreased work performance ${ }^{39}$ and dyspnea on exertion were common symptoms, which were because of cardiovascular compromise. Work capacity is assessed by aerobic capacity, endurance, energetic efficiency, voluntary activity and work productivity. The presumed mechanism for this effect is the reduced oxygen transport associated with anemia; tissue iron deficiency may also play a role through reduced cellular oxidative capacity. Iron plays an essential role in oxidative energy production.

Pallor, nail changes and edema were the most common clinical finding in anemic patients. People who have irondeficiency anemia may have an unusual craving for nonfood items, such as ice, dirt, paint, or starch. This craving is called pica (PI-ka or PE-ka). Some people who have iron-deficiency anemia develop restless legs syndrome (RLS). RLS is a disorder that causes a strong urge to move the legs.

This urge to move often occurs with strange and unpleasant feelings in the legs. People who have RLS often have a hard time sleeping. Iron-deficiency anemia can put children at greater risk for lead poisoning and infections. Study conducted by Chang Hyung Hong et al $(2013)^{37}$ found that among older adults, anemia is associated with an increased risk of developing dementia. If anemias especially iron deficiency occurs during infancy, it may affect adversely on auditory and visual development ${ }^{40}$.

Pallor of the disc was the most common fundus finding which is found in $40 \%$ cases. Severity of retinal manifestations in anemia depends upon severity of anemia. Ocular manifestations of severe anemia have been increasingly recognized and anemia of varied reasons can result in different ocular manifestations. Nushrat Shaheen et al (2005) $)^{35}$ also describe many ocular manifestation in anemia like conjuctival pallor, retinal abnormalities like hemorrhages, tortuous veins, exudates and disc edema and posterior pole pallor cases.

Microcytic hypochromic picture was most common finding on peripheral smear examination $(59 \%)$, followed by dimorphic picture in $26 \%$ patients. Iron deficiency was the most common cause of microcytic hypochromic picture, combined deficiency of iron and vitamin 
B12/folic acid were the most common cause of dimorphic anemia. Iron deficiency anemia and thalassemia trait are the commonest causes of microcytic anemia, but they may coexist. Serum ferritin and haemoglobin $\mathrm{A}_{2}$ quantitation are the two most important investigations to distinguish between iron deficiency anemia and thalassemia trait ${ }^{36}$.

The absence of iron stores in the bone marrow remains the most definitive test for differentiating iron deficiency from the other microcytic states, ie, anemia of chronic disease, thalassemia, and sideroblastic anemia ${ }^{41}$. Vitamin $B_{J 2}$ deficiency was the most common cause of megaloblastic anemia. Sickle cell anemia and aplastic anemia were the common causes of normocytic normochromic anemia.

So blood smear is of great importance in the differential diagnosis of macrocytic anemias. For patients in whom there is a deficiency of vitamin B12 or folic acid, the blood smear shows not only macrocytes but also oval macrocytes and hypersegmented neutrophils. The blood smear is generally less important in the differential diagnosis of the microcytic anemia. ${ }^{38}$

\section{Conclusion}

Nutritional deficiency anemia is the most common cause of anemia among population, and iron deficiency is the most common nutritional deficiency in population. Low socio- economic class, vegetarian diet, false dietary habits, worm infestation, multiple pregnancy are the most common risk factor related with anemia.

By taking simple and effective measures like dietary adjustment and fortification of food with iron and other micronutrients, we can decreases the occurrence of nutritional anemia, and will also decrease the morbidity and mortality related to anemia. Iron deficiency anemia in children can affect long-term cognitive function.

\section{Funding: Nil}

\section{Conflict of interest: Nil}

\section{Permission from IRB: Yes}

\section{References}

1. McLean E, Cogswell M, Egli I, Wojdyla D, de Benoist B. Worldwide prevalence of anaemia, WHO Vitamin and Mineral Nutrition Information System, 1993-2005. Public Health Nutr. 2009;12(4):444-54.

2. Maurício S Leite, Andrey M Cardoso, Carlos EA Coimbra, James R Welch, Silvia A Gugelmin, Pedro Cabral I Lira, Bernardo L Horta, Ricardo Ventura Santos and Ana Lúcia Escobar. Prevalence of anemia and associated factors among indigenous children in Brazil: results from the First National Survey of Indigenous People's Health and Nutrition.Nutrition Journal 2013;12:69.

3. Milman N. Anemia--still a major health problem in many parts of the world. Ann Hematol. 2011;90(4):36977.

4. Khambalia AZ, Aimone AM, Zlotkin SH. Burden of anemia among indigenous populations. Nutr Rev. 2011;69(12):693-719.

5. Prakash V Kotecha. Nutritional Anemia in Young Children with Focus on Asia and India. Indian J Community Med. 2011; 36(1): 8-16.

6. Pasricha SR, Black J, Muthayya S, Shet A, Bhat V, Nagaraj S, Prashanth NS, Sudarshan H, Biggs BA, Shet AS: Determinants of anemia among young children in rural India. Pediatrics 2010, 26:e140-e149.

7. R.G. Viveki1, A.B. Halappanavar, P.R. Viveki, S.B. Halki, V.S. Maled, P.S. Deshpande. Prevalence of Anaemia and Its Epidemiological Determinants in Pregnant Women. Al Ameen J Med Sci.2012;5(3):216-23.

8. K. Kalaivani. Prevalence \& consequences of anaemia in pregnancy. Indian J Med Res. 2009;130: 627-33.

9. Lindsay H Allen. Anemia and iron deficiency: effects on pregnancy outcome. Am J Clin Nutr. 2000 May;71(5):1280s-84s.

10. Chang S, Zeng L, Brouwer ID, Kok FJ, Yan H. Effect of iron deficiency anemia in pregnancy on child mental development in rural China. Pediatrics. 2013;131(3):e75563.

11. Theresa O. Scholl, Thomas Reilly. Anemia, Iron and Pregnancy Outcome. J. Nutr. 2000; 130(2): 443S-47S.

12. Agaoglu L, Torun O, Unuvar E, Sefil Y, Demir D. Effects of iron deficiency anemia on cognitive function in children. Arzneimittelforschung. 2007;57(6A):426-30.

13. Wang B, Zhan S, Gong T, Lee L. Iron therapy for improving psychomotor development and cognitive function in children under the age of three with iron deficiency anaemia. chrane Database Syst Rev. 2013 Jun 6;6: CD001444.(doi: 10.1002/14651858. CD001444. pub2.) 
14. Radlowski EC, Johnson RW. Perinatal iron deficiency and neurocognitive development. . Front Hum Neurosci. 2013;7:585.

15. Karine Tolentino, Jennifer F. Friedman. An Update on Anemia in Less Developed Countries. Am J Trop Med Hyg. 2007;77(1): 44-51.

16. Nynke van den Broek. Anaemia and micronutrient deficiencies, Reducing maternal death and disability during pregnancy. Br Med Bull (2003) 67 (1): 149-160.

18. Coyer SM. Anemia: diagnosis and management. J Pediatr Health Care.2005;19(6):380-5.

19. Kumar A. National nutritional anaemia control programme in India. Indian J Public Health. 1999;43(1):35.

20. Gururaj N, Sivapathasundharam B, Sumathy N. Cytological findings in iron deficiency anemia. Indian $\mathrm{J}$ Dent Res. 2004;15(4):126-28.

21. Panagiotou JP, Douros K. Clinicolaboratory findings and treatment of iron-deficiency anemia in childhood. Pediatr Hematol Oncol. 2004;21(6):521-34.

22. Carlo Brugnara. A Hematologic "Gold Standard" for Iron-deficient States. Clinical Chemistry. 2002; 48(7): 981-82.

23. Florence A, Joseph J.M, Steven H.Y. Megaloblastic Anemia and Other Causes of Macrocytosis. Clinical Medicine \& Research. 2006; 4(3): 236-41.

24. Antony AC. Megaloblastic anemia. In: Hoffman R, Benz EJ, Shattil SJ, Furie B, Cohen HJ, Silberstein LE, et al. (eds). Hematology. Basic principles and practice. 4th ed. Edinburgh:Churchill Livingstone; 2005: 519-56.

25. Carmel R. Megaloblastic anemias: Disorders of impaired DNA synthesis. In: Greer JP, Foerster J, Lukens JN, Rodgers GM, Paraskevas F, Glader B (eds). Wintrobe's clinical hematology. 11th ed. Philadelphia:Lippincott Williams and Wilkins; 2004:1367-95.

26. Yusufji D, Mathan VI, Baker SJ. Iron, folate and vitamin B12 nutrition in pregnancy: A study of 1000 women from southern India. Bull World Health Organ 1973;48:15-22.
27. Katar S, Nuri Ozbek M, Yaramiş A, Ecer S. Nutritional megaloblastic anemia in young Turkish children is associated with vitamin B-12 deficiency and psychomotor retardation. J Pediatr Hematol Oncol. 2006;28(9):559-62.

28. Louis Lowenstein, Lauder Brunton, and Yang-Shu Hsieh. Nutritional Anemia and Megaloblastosis in Pregnancy. Can Med Assoc J. 1966; 94(13): 636-45.

29. Chaudhary SM, Dhage VR. A study of anemia among adolescent females in the urban area of Nagpur. Indian $\mathbf{J}$ Community Med. 2008;33:243-5.

30. Bhasin A, Rao MY. Characteristics of Anemia in Elderly: A Hospital Based Study in South India. Indian J Hematol Blood Transfus. 2011; 27(1): 26-32.

31. Panigrahi A, Sahoo PB. Nutritional anemia and its epidemiological correlates among women of reproductive age in an urban slum of Bhubaneswar, Orissa. Indian J Public Health. 2011;55:317-20.

32. WHO. Haemoglobin concentrations for the diagnosis of anaemia and assessment of severity. Vitamin and Mineral Nutrition Information System. Geneva, World Health Organization, 2011 (WHO/NMH/NHD/MNM/ 11.1)

33. Verma M, Chhatwal J, Kaur G.Prevalence of anemia among urban school children of Punjab. Indian Pediatr. 1998 Dec;35(12):1181-6.

34. Upadhyay S. Kumar A. R. Singh R. Raghuvanshi and Singh, B. B. Nutritional Status and Knowledge of Hill Women on Anemia: Effect of Various Socio-demographic Factors, J Hum Ecol. 2011; 33(1): 29-34.

35. Kakkar R, Kakkar M, Kandpal SD, Jethani S. Study of anemia in adolescent school girls of Bhopal. Indian J Community Health 2010;22:38-40.

36. Nusrat Shaheen,Junaid S. Wani,A.R. Nasti,M.I.Quadri. Ocular Manifestation in Anemia-A Clinical Study. JK-Practitioner 2005;12(3):128-130.

37. W Owen Uprichard, James Uprichard. Investigating microcytic anaemia. BMJ2013;346:f3154

38. Chang Hyung Hong, Cherie Falvey, Tamara B. Harris, Eleanor M. Simonsick, Suzanne Satterfield, MD, Luigi Ferrucci, Andrea L. Metti, Kushang V. Patel, Kristine Yaffe. Anemia and risk of dementia in older adults. Neurology . 2013; 81( 6): 528-533.

Available online at: $\underline{\text { www.ijmrr.in }} 51$ | P a g e 
39. Barbara J. Bain. Diagnosis from the Blood Smear. N Engl J Med. 2005;353:498-507.

40. Haas JD, Brownlie T IV. Iron deficiency and reduced work capacity: a critical review of the research to determine a causal relationship. J Nutr. 2001;131(2 suppl):676S-88S; discussion 688S-90S.
41. Algarin C, Peirano P, Garrido M, Pizarro F, Lozoff B. Iron deficiency anemia in infancy: long-lasting effects on auditory and visual system functioning. Pediatr Res. 2003;53:217-23.

42. Massey AC. Microcytic anemia. Differential diagnosis and management of iron deficiency anemia. Med Clin North Am. 1992;76(3):549-66.

\section{How to cite this article?}

Ratre BK, Patel NP, Patel U, Jain R, Sharma VK. Clinical and Epidemiological profile of Anemia in central India. Int J Med Res Rev 2014;2(1):45-52, 10.17511/ijmrr.2014.i01.09 